\title{
Brucellosis as a trigger agent for Henoch-Schönlein purpura
}

\author{
Akgun $\mathrm{C}^{1}$, Akbayram $\mathrm{S}^{1}$, Guner $\mathrm{S}^{2}$, Aktar $\mathrm{F}^{1}$, Temel $\mathrm{H}^{1}$, Basaranoglu $\mathrm{M}^{1}$ \\ Department of Pediatrics, University of Yuzuncu Yil, School of Medicine, Van, Turkey. \\ cihangirakgun@gmail.com
}

\begin{abstract}
Vasculitis in childhood is a result of a spectrum of causes ranging from idiopathic conditions with primary vessel inflammation to syndromes after exposure to recognized antigenic triggers, such as infectious agents and drugs causing hypersensitivity reactions. Henoch-Schönlein purpura (HSP) is the most common vasculitis of childhood. Although there is often a history of a recent or simultaneous upper respiratory tract infection, no consistent causative organism is found. We report an 11-year old boy with HSP and brucellosis and we speculated that brucellosis was the trigger agent for HSP (Ref. 13). Full Text in PDF www.elis.sk.

Key words: brucellosis, trigger agent, Henoch-Schönlein purpura, vasculitis, infectious agents, drug, hypersensitivity reactions, primary vessel inflammation.
\end{abstract}

Henoch-Schönlein purpura (HSP) is characterized by nonthrombocytopenic purpura, arthritis and arthralgia, abdominal pain and gastrointestinal hemorrhage, and glomerulonephritis (1). It is one of the most common vasculitides of childhood (2). HSP was first recognized by Heberden in 1801 and first described as an association between purpura and arthritis by Schönlein in 1837. In 1874 and in 1899, Henoch added descriptions of gastrointestinal involvement and renal involvement, respectively $(3,4)$. The diagnostic criteria of HSP were modified by the European League against Rheumatism/ Paediatric Rheumatology European Society (EULAR/PReS) as follows (5).

\section{Classification criteria for Henoch-Schönlein purpura}

Palpable purpura (mandatory criterion) in the presence of at least one of the following four features:

Diffuse abdominal pain

Any biopsy showing predominant IgA deposition

Arthritis (Acute, any joint) or arthralgia

Renal involvement (any haematuria and/or proteinuria)

Many reports have implicated infections such as parvovirus B19, hepatitis B virus, hepatitis C virus, human immonudeficiency virus, Streptococcus species particularly $\beta$ - hemolytic streptococci, Salmonella species, Shigella species, Staphylococcus aureus, medications such as antibiotics, angiotensin converting enzyme inhibitors, non-steroidal anti-inflammatory (NSAI) agents and toxins such as vaccinations, insect bites and food allergy as a

${ }^{1}$ Department of Pediatrics, University of Yuzuncu Yil, School of Medicine, Van, Turkey, and ${ }^{2}$ Department of Orthopedics University of Yuzuncu Yil, School of Medicine, Van, Turkey

Address for correspondence: C. Akgun, MD, University of Yuzuncu Yil School of Medicine, Department of Pediatric Nephrology, 65200, Van, Turkey.

Phone: +90.533 .6513323$ potential trigger for this disease. $(6,7)$ In this study, we report an 11- year old boy with HSP and brucellosis as a potential trigger infection.

\section{Case report}

The 11-year old boy was referred from orthopedics department to our clinic because of arthritis, fever, weight loss, abdominal pain, and purpura skin lesion of the lower legs. His past history was unremarkable except for consumption of fresh unpasteurized cheese. Physical examination revealed a blood pressure of $120 / 85 \mathrm{mmHg}$, bilateral symmetric palpable purpura on the lower extremities, abdominal defense-tenderness and swelling on the bilateral ankle joints. On admission, laboratory investigations revealed hemoglobin $11.8 \mathrm{~g} / \mathrm{dl}$, white blood cell count $9900 / \mu \mathrm{L}$, platelet count $319,000 / \mu \mathrm{L}$, C-reactive protein $19.1 \mathrm{mg} / \mathrm{dl}$, blood urea nitrogen $7 \mathrm{mg} / \mathrm{dl}$, and serum creatinine $0.68 \mathrm{mg} / \mathrm{dl}$. Serum electrolyte, liver enzymes, blood coagulation tests, antinuclear antibody, rheumatoid factor, antistreptolysin O, serum IgA and urinalysis were within normal levels. The brucella agglutination test was $\geq 1 / 1280$. On skin punch biopsy, capillaries and venules of the dermis were affected by a leukocytoclastic vaskulitis with vessel wall necrosis and perivascular accumulation of polymorphonuclear leukocytes and mononuclear cells. Immunofluorescence microscopy was positive for IgA.

The patient was hospitalized with the diagnosis of HSP and brucellosis; antihistaminic and NSAI drugs were initiated for pruritis and arthritis, respectively and rifampycin and tetracycline were initiated for brucellosis. On the 2nd day of admission, the patient was discharged with these medications. Two weeks after discharging from the hospital, he was readmitted to our pediatric nephrology outpatient clinic for follow up and his purpura on the lower extremities was extinguished and the swelling on the bilateral ankle joints was relieved. Antihistaminic and NSAI drugs were discontinued and rifampycin and tetracycline were continued 
totally for six weeks. On the 3rd month of follow-up, he was fully recovered without any systemic involvement of HSP.

\section{Discussion}

HSP is defined as vasculitis with predominantly IgA deposits in the walls of small vessels in the skin, gastrointestinal tract and kidney associated with arthralgias or arthritis (8.) The etiology is unknown, but HSP follows an upper respiratory infection (9). Infection agents, some medications and some toxins were reported as a trigger for HSP (7). Zucchini et al reported two cases of HSP associated with acute salmonella enterocolitis (10). Courtney PA et al reported a case of vasculitis occurring 7 days after meningitis $\mathrm{C}$ vaccination in a 17 year old girl (11). In different studies, hepatitis $\mathrm{A}$ and $\mathrm{B}$, Mycoplasma pneumonia, Bartonella henselae and Parvovirus B19 have been implicated as a trigger for HSP (1).

Human brucellosis, caused by organisms of the genus Brucella, is still a major public health problem worldwide. Brucella abortus (cattle), B. melitensis (goat/sheep), B. suis (swine), and B. canis (dog) are the most common organisms responsible for human disease (12). It is a systemic illness that can be very difficult to diagnose in children without a history of animal or food exposure. Our patient had a history of consumption of fresh unpasteurized cheese. In the diagnosis of brucellosis, the routine laboratory investigations of the blood generally are not helpful; instead the serum agglutination test is the most widely used and detects antibodies against B. abortus, B. melitensis, and B. suis. In our patient the brucella agglutination test was $\geq 1 / 1280$ and we speculated that brucella was a trigger infection for HSP. Massasso et al, reported a case of HSP with brucellosis and they concluded the ability of brucellosis to mimic systemic vasculitic disease, in particular HSP (13). In their study, they showed the leukocytoclastic vasculitis with IgA immunofluorescence of dermal vessels consistent with HSP, so we thought, both in our case and in theirs, brucellosis was the trigger agent for HSP. In conclusion, we would like to show that our case suggests the possibility of brucellosis being a trigger agent of HSP.

\section{References}

1. Cassidy JT, Petty RE. Leukocytoclastic vasculitis. In: Cassidy JT, Petty RE, Laxer RM, Lindsley CB (Eds). Textbook for Paediatric Rheumatology. Philadelphia: Elsevier, Saunders company, 2005, 496-511.

2. Ballinger S. Henoch-Schonlein purpura. Curr Opin Rheumatol 2003; 15 (5): 591-594.

3. Yukihiko K, Suzuki H. Henoch-Schönlein Nephritis. In: Geary DF, Schaefer F (Eds). Comprehensive Pediatric Nephrology. Philadelphia: Mosby-Elsevier company, 2008, 343-351.

4. Deng F, Lu L, Zhang Q, Hu B, Wang SJ, Huang N. Henoch-Schönlein purpura in childhood: treatment and prognosis. Analysis of 425 cases over a 5-year period. Clin Rheumatol, 2009, Dec 23.

5. Ozen S, Ruperto N, Dillon MJ, Bagga A, Barron K, Davin JC, Kawasaki T, Lindsley C, Petty RE, Prieur AM, Ravelli A, Woo P. EULAR/PReS endorsed consensus criteria for the classification of childhood vasculitides. Ann Rheum Dis, 2006; 65 (7): 936-941.

6. Matsukura H, Ohtsuki A, Fuchizawa T, Miyawaki T. Acute poststreptococcal glomerulonephritis mimicking Henoch-Schönlein purpura. Clin Nephrol 2003; 59 (1): 64-65.

7. Kaplan BS. Henoch-Schönlein Purpura Nephritis. In: Kaplan BS, Meyers KEC (Eds). Pediatric Nephrology and Urology. Philadelphia: MosbyElsevier company, 2005, 141-146.

8. Davin JC, Weening JJ. Henoch-Schönlein purpura nephritis: an update. Eur J Pediatr 2001; 160 (12): 689-695.

9. Miller ML, Pachman LM. In: Kliegman RM, Behrman RE, Jenson HB, Stanton BF (Eds). Nelson Textbook of Pediatrics. Philadelphia: Elsevier, Saunders company, 2007, 1042-1049.

10. Zucchini A, Manfredi R. Schoenlein-Henoch syndrome and salmonella infection: a new association? Minerva Pediatr 1992; 44 (11): 559-563.

11. Courtney PA, Patterson RN, Lee RJ. Henoch-Schönlein purpura following meningitis C vaccination. Rheumatology (Oxford) 2001; 40 (3): 345-346.

12. Nelson, Schutze GE, Jacobs RF. In: Kliegman RM, Behrman RE, Jenson HB, Stanton BF (ds). Nelson Textbook of Pediatrics. Philadelphia: Elsevier, Saunders company, 2007, 1214-1216.

13. Massasso D, Gibson K. Brucellosis mimicking Henoch-Schönlein purpura. Med J Aust 2007; 186 (11): 602-603.

Received February 16, 2010. Accepted April 15, 2012 